\title{
DISTRIBUSI ASET DAN KEKAYAAN YAYASAN: Perspektif Perundang-undangan
}

\author{
Nurul Hudayanti \\ Universitas Andi Djemma Palopo
}

\begin{abstract}
The Law of the Foundation Number 28 of 2004 regulates the property of the foundation forbidden to be transferred or distributed directly or indirectly, whether in the form of salary, wages, or honorarium, or any other form which can be valued with money to the supervisor, board, and supervisor. Exceptions are granted to the executor of daily activities not affiliated with the founders, supervisors and supervisors and to undertake the direct and full management of foundations, established by the supervisor, on the basis of the foundation's wealth. The provision of wages, wages, or honors to the board of foundations that do not meet the requirements of Article 5 of the Foundation Law shall be deemed to have taken or transferred the property of the foundation and that is included as a crime. From the research results it appears that there are administrators who violate the provisions of Article 70. However, there is no sanction to the board.
\end{abstract}

\section{Keywords:}

Foundation, Wage, Salary, Honor, Act, Criminal

\begin{abstract}
Abstrak
Undang-undang Yayasan Nomor 28 Tahun 2004 mengatur kekayaan yayasan dilarang untuk dialihkan atau dibagikan secara langsung maupun tidak langsung, baik dalam bentuk gaji, upah, ataupun honor, atau bentuk lain yang dapat dinilai dengan uang kepada pembina, pengurus, dan pengawas. Pengecualian diberikan kepada pelaksana kegiatan harian yang tidak terafiliasi dengan pendiri, pembina, dan pengawas serta melaksanakan kepengurusan yayasan secara langsung dan penuh, ditetapkan oleh pembina, berdasarkan kemampuan kekayaan yayasan. Pemberian gaji, upah, atau honor kepada pengurus yayasan yang tidak memenuhi syarat pada Pasal 5 Undang-undang Yayasan dianggap telah mengambil atau mengalihkan kekayaan yayasan dan itu termasuk sebagai tindak pidana. Dari hasil penelitian nampak bahwa ada pengurus yang melanggar ketentuan Pasal 70. Akan tetapi, tidak ada pemberian sanksi kepada pengurus tersebut.
\end{abstract}

Kata Kunci:

Yayasan, Upah, Gaji, Honor, Undang-undang, Pidana 


\section{A. PENDAHULUAN}

ejak tanggal 6 Agustus 2001, Indonesia telah memiliki suatu Undang-undang yang mengatur tentang yayasan. Suatu perjalanan yang panjang, dimulai dari $\checkmark$ berbagai naskah akademik Rancangan Undang-undang yang lahir silih berganti, pembicaraan yang panjang di DPR. Akhirnya 45 tahun setelah Belanda memiliki Undang-undang yayasan, baru kini Indonesia memiliki Undang-undang mengenai persoalan yang sama. Undang-undang Nomor 16 Tahun 2001 tentang yayasan berlaku sejak tanggal 16 Agustus 2002. Selanjutnya, pada tanggal 6 Oktober 2004 melalui lembaran Negara Republik Indonesia Tahun 2004 Nomor 115 disahkan Undang-undang Nomor 28 Tahun 2004 tentang perubahan atas Undang-undang Nomor 16 Tahun 2001 tentang Yayasan. ${ }^{1}$

Di Indonesia persoalan yayasan muncul disebabkan sejumlah yayasan yang didirikan karena kewenangan kekuasaan atau instansi telah memanfaatkan berbagai fasilitas yang diberikan oleh kewenangan itu, baik berupa monopoli, pemberian order tertentu, maupun keringanan atau bahkan pembebasan pajak. Yayasan tidak dapat dan tidak boleh menjadi suatu badan hukum, seperti Perseroan Terbatas yang bertujuan untuk mencari keuntungan. Akan tetapi, tentu saja yayasan boleh untuk memperoleh keuntungan, dan berarti melakukan kegiatan usaha atau mendirikan badan usaha, agar tidak bergantung selamanya dari sumbangan, tetapi keuntungan atau hasil dari kegiatan usaha yang diperoleh haruslah semata-mata dipergunakan atau diperuntukkan bagi tujuan sosial dan kemanusiaan. Termasuk pemberian gaji, upah dan/atau honor kepada organ yayasan yaitu pembina, pengurus dan pengawas tidak diperbolehkan. Hal ini diatur dalam Pasal 5 ayat (1) undang-undang yayasan yang menetapkan bahwa:

"Kekayaan Yayasan baik berupa uang, barang, maupun kekayaan lain yang diperoleh Yayasan berdasarkan Undang-undang ini, dilarang dialihkan atau dibagikan secara langsung atau tidak langsung, baik dalam bentuk gaji, upah, maupun honorarium, atau bentuk lain yang dapat dinilai dengan uang kepada Pembina, Pengurus, dan Pengawas".

Sejak diubahnya Undang-undang Nomor 16 Tahun 2001 tentang Yayasan menjadi Undang-undang Nomor 28 Tahun 2004, ada hal yang berbeda dalam pengaturan pembagian kekayaan yayasan kepada organ yayasan terutama kepada pembina, pengurus dan pengawas. Dalam Undang-undang Nomor 16 Tahun 2001 pembagian kekayaan tidak diperbolehkan, kecuali kepada pelaksana kegiatan yayasan. Pasal 35 ayat (3) Undang-undang Nomor 16 menjelaskan mengenai pelaksana kegiatan yayasan adalah pengurus harian yayasan yang melaksanakan kegiatan yayasan sehari-hari. Sedangkan dalam Undang-undang Nomor 28 Tahun 2004 pembagian kekayaan dibolehkan tetapi hanya kepada pengurus yang bukan pendiri yayasan, tidak terafiliasi (mempunyai hubungan keluarga sampai derajat

\footnotetext{
${ }^{1}$ Chatamarrasjid Ais. 2006. Badan Hukum Yayasan Cet, II. PT Citra Aditya Bakti. Bandung, hal 1.
} 
ketiga, dan perkawinan), dengan pembina, pengurus, dan pengawas dengan yang melaksanakan kepengurusan yayasan secara langsung. Pembagian kekayaan tersebut harus disesuaikan dengan keadaan kekayaan yayasan. Hal inilah yang menjadi salah satu masalah yang sering didapatkan, apakah organ yayasan dalam hal ini pembina, pengurus, dan pengawas dapat memperoleh gaji, upah, dan/atau honor atas pekerjaan yang dilakukan.

Undang-undang Nomor 16 Tahun 2001 tentang Yayasan yang kemudian direvisi menjadi Undang-undang Nomor 28 Tahun 2004, pada satu sisi telah memberikan kepastian hukum dan landasan hukum bagi yayasan di Indonesia, tetapi pada sisi lain juga menimbulkan beberapa pertanyaan. Terlepas dari beberapa kekurangannya, undang-undang ini merupakan dasar hukum yang memberikan kepastian hukum dalam mendirikan yayasan yang sudah berkembang, jauh sebelum undang-undang ini ditetapkan. Undang-undang ini sangat dibutuhkan karena banyaknya yayasan di Indonesia saat ini, mulai dari yayasan rumah sakit bersalin yang mengurus kelahiran sampai yayasan yang mengurus kematian, dari yayasan yang mengurus pemulung sampai yayasan yang memiliki lebih dari 30 bidang usaha dalam bentuk perseroan terbatas. ${ }^{2}$

Persoalannya adalah undang-undang yayasan melarang pemberian gaji, upah, atau honor bagi organ yayasan yang harus diatur dalam Anggaran Dasar dan Anggaran Rumah Tangga pada masing-masing yayasan. Berkaitan dengan hal tersebut, dikeluarkannya Undang-undang Yayasan yang baru, dapat terjadi suatu pembaruan yang lebih baik dalam mengatur kehidupan yayasan di Indonesia serta menjamin kepastian dan ketertiban hukum agar yayasan berfungsi sesuai dengan maksud dan tujuannya berdasarkan prinsip keterbukaan dan akuntabilitas.

\section{B. PENGERTIAN YAYASAN}

Sebagaimana dalam Pasal 1 Undang-undang Nomor 28 Tahun 2004 tentang Yayasan, menetapkan bahwa yang dimaksud dengan yayasan adalah "badan hukum yang terdiri atas kekayaan yang dipisahkan dan diperuntukkan untuk mencapai tujuan di bidang sosial, keagamaan, dan kemanusiaan, yang tidak mempunyai anggota". Berdasarkan pengertian itu, maka status badan hukum yayasan yang semula diperoleh dari sistem terbuka penentuan suatu badan hukum (het Open system van Rechtspersonen), beralih berdasarkan sistem tertutup (de Gesloten system van Rechtspersonen). Artinya, sekarang yayasan menjadi badan hukum karena undang-undang atau berdasarkan undang-undang, bukan berdasarkan sistem terbuka, yang berlandaskan pada kebiasaan, doktrin dan ditunjang oleh yurisprudensi. ${ }^{3}$

Suatu yayasan dapat didirikan dengan tata cara yang telah ditetapkan oleh Undang-undang Yayasan. Dalam Pasal 9 ayat (1) diatur bahwa, yayasan dapat didirikan oleh satu orang atau lebih dengan memisahkan harta kekayaan pendirinya,

\footnotetext{
${ }^{2}$ Chatamarrasjid Ais. 2006. Badan Hukum Yayasan Cet, II. PT Citra Aditya Bakti. Bandung, hal. 91.

${ }^{3}$ Chatamarrasjid Ais. 2006, Badan Hukum Yayasan Cet.II, Bandung: PT Citra Aditya Bakti, hal.2.
} 
sebagai kekayaan awal. Ketentuan ini menunjukkan, pendirian yayasan tidak dengan dasar adanya suatu perjanjian. Jika sebuah yayasan pendirinya hanya satu orang, jelas tidak mungkin ada perjanjian yang dibuat oleh pendirinya. Jika pendirinya lebih dari satu orang, ketentuan Undang-undang Yayasan tidak mengharuskan dengan membuat perjanjian lebih dahulu. Tidak ada satu pun pasal dalam Undang-undang Yayasan yang mengharuskan seperti itu.

\section{ORGAN YAYASAN}

Yayasan sebagai sebuah badan hukum dapat dibedakan hak dan kewajiban, harus memiliki alat perlengkapannya sehingga mampu mengurus dirinya sebagaimana manusia pada umumnya. Seperti halnya badan hukum perseroan terbatas yang di dalamnya terdapat RUPS (Rapat Umum Pemegang Saham), direksi dan komisaris, dimana ketiga organ tersebut saling bekerja sama mengurus perseroan sesuai dengan tugasnya masing-masing sehingga perseroan mampu melaksanakan hak dan kewajibannya di bidang hukum perusahaan. Untuk yayasan alat perlengkapannya telah ditentukan dalam Undang-undang Yayasan yaitu pembina, pengurus, dan pengawas.

\section{Pembina}

Dalam Pasal 28 Undang-undang Yayasan, yang dimaksud dengan Pembina adalah "Organ yayasan yang mempunyai kewenangan yang tidak diserahkan kepada pengurus atau pengawas oleh undang-undang ini atau anggaran dasar". Anggota pembina diangkat dari orang-perseorangan yang merupakan pendiri yayasan dan/atau mereka yang berdasarkan rapat anggota pembina dinilai mempunyai dedikasi yang tinggi untuk mencapai maksud dan tujuan yayasan yang jumlahnya bisa lebih dari satu orang. Dengan beberapa orang personal yang ada dalam pembina, maka susunan lembaganya dapat terdiri dari ketua, wakil, dan anggota. Dapat pula ketua maupun wakil merangkap menjadi anggota pembina.

Pembina merupakan organ tertinggi dalam sebuah yayasan, anggota pembina tidak boleh merangkap sebagai anggota pengurus maupun anggota pengawas. Larangan tersebut diatur secara tegas dalam ketentuan Pasal 29 Undang-undang Yayasan. Selaku organ tertinggi, pembina memiliki kewenangan untuk menilai hasil pekerjaan pengurus dan pengawas setiap tahun, hal ini tampak dalam laporan pengurus dan pengawas, kemudian disahkan dalam Rapat Pembina. Rapat Pembina dapat saja menolak pengesahan laporan tersebut jika isinya ternyata tidak benar.

\section{Pengurus}

Pengurus adalah organ yayasan yang melaksanakan kepengurusan yayasan. Segala sesuatu mengenai pengurus diatur dalam Pasal 31 sampai dengan Pasal 39 Undang-undang Yayasan. Pengurus merupakan organ eksekutif yang bertanggungjawab sepenuhnya atas kepengurusan yayasan baik dalam maupun di 
luar pengadilan, sesuai dengan asas persona standi in judicio. ${ }^{4}$ Pengurus bertanggungjawab secara pribadi apabila yang bersangkutan dalam menjalankan tugasnya tidak sesuai dengan anggaran dasar. Sebagaimana diatur dalam Pasal 32 ayat (1) Undang-undang Yayasan bahwa pengurus yayasan diangkat oleh pembina berdasarkan keputusan rapat pembina untuk jangka waktu selama 5 tahun dan dapat diangkat kembali. Pengangkatan, pemberhentian, dan penggantian pengurus harus dilakukan sesuai dengan ketentuan yang terdapat dalam anggaran dasar yayasan. Pengurus dapat diganti setiap sebelum masa jabatannya terakhir jika dinilai oleh pembina melakukan tindakan yang merugikan yayasan. Adanya pembatasan masa jabatan itu tujuannya untuk menghindari agar jangan sampai kekuasaan pengurus menjadi tidak terbatas di tangan sekelompok orang. Selain itu dengan masuknya pengurus baru dalam yayasan, dimaksudkan untuk penyegaran dalam kepengurusan yayasan, dan untuk kepentingan demi meningkatkan kemajuan dalam mencapai maksud dan tujuan yayasan.

\section{Pengawas}

Selain pembina dan pengurus, organ yayasan yang lain adalah pengawas. Organ ini mempunyai tugas mengawasi pekerjaan pengurus yayasan. Dalam Pasal 40 ayat (1) ditetapkan bahwa Pengawas adalah organ yayasan yang bertugas melakukan pengawasan serta memberi nasihat kepada Pengurus dalam menjalankan kegiatan Yayasan. Hal ini dimaksudkan melakukan pengawasan saja tidaklah cukup jika pengawas tidak memberi jalan keluarnya berupa nasihat-nasihat kepada para pengurus yayasan.

Pengawas diangkat oleh pembina untuk jangka waktu 5 tahun dan dapat diangkat kembali untuk 1 kali masa jabatan (Pasal 44 ayat 1). Apabila terjadi penggantian pengurus, maka pembina yayasan wajib memberitahukan secara tertulis kepada Menteri Hukum dan HAM, dan kepada instansi terkait. Penggantian ini harus sesuai dengan ketentuan anggaran dasar atau pengadilan dapat membatalkannya atas permintaan yang berkepentingan, dan kejaksaan dalam hal mewakili kepentingan umum.

\section{PEMBERIAN GAJI, UPAH, DAN/ATAU HONOR KEPADA PENGURUS YAYASAN}

Pengurus menempati kedudukan sentral dalam mengendalikan Yayasan dan hal ini memberikan tanggung jawab yang besar, baik di dalam maupun di luar yayasan. Pengesahan Undang-undang Nomor 16 Tahun 2001 tentang Yayasan yang kemudian direvisi menjadi Undang-undang Nomor 28 Tahun 2004, mengatur berbagai hal termasuk mengenai tugas dan pertanggungjawaban organ Yayasan, baik internal maupun eksternal. Pertanggungjawaban pengurus dapat dihubungkan

\footnotetext{
${ }^{4}$ Chatamarrasjid Ais. 2006, Badan Hukum Yayasan Cet.II, Bandung: PT Citra Aditya Bakti, hal.106.
} 
dengan tugas dan wewenang yang melandasi kegiatan para pengurus tersebut. Dalam hubungan ini dicari doktrin yang melandasi tugas dan kewajiban seorang pengurus, yang pada akhirnya harus dipertanggungjawabkan.

Pengurus dalam melaksanakan tugasnya berdasarkan kepercayaan yang diberikan oleh pembina/pendiri (doktrin fiduciary duty), untuk kepentingan yayasan secara keseluruhan dan bukan untuk kepentingan pribadi organ yayasan, harus sesuai dengan tujuan dan maksud yayasan. Adapun prinsip-prinsip dalam doktrin fiduciary adalah sebagai berikut:

$>$ Pengurus di dalam melaksanakan tugasnya tidak boleh bertujuan untuk kepentingan pribadi ataupun kepentingan pihak ketiga. Begitu juga bila terdapat kepentingan yang bertentangan dengan yayasan, maka harus diketahui oleh pengurus yayasan yang lain (the conflict rule).

$>\quad$ Pengurus tidak boleh memanfaatkan kedudukannya sebagai pengurus untuk memperoleh keuntungan, baik untuk dirinya sendiri maupun pihak ketiga, kecuali atas persetujuan yayasan (the profit rule).

$>\quad$ Pengurus tidak boleh mempergunakan atau menyalahgunakan yayasan untuk kepentingan sendiri dan/atau pihak ketiga (the misappropriation rule). ${ }^{5}$

\section{Pengertian Gaji, Upah, dan Honor}

Gaji

Gaji adalah salah satu hal yang penting bagi setiap karyawan yang bekerja dalam suatu perusahaan, karena dengan gaji yang diperoleh seseorang dapat memenuhi kebutuhan hidupnya. Hasibuan menyatakan bahwa, gaji adalah balas jasa yang dibayar secara periodik kepada karyawan tetap serta mempunyai jaminan yang pasti. Pendapat lain dikemukakan oleh Handoko, gaji adalah pemberian pembayaran finansial kepada karyawan sebagai balas jasa untuk pekerjaan yang dilaksanakan dan sebagai motivasi pelaksanaan kegiatan di waktu yang akan datang. Selain pernyataan Hasibuan dan Handoko, ada pernyataan lainnya mengenai gaji dari Hariandja, yaitu Gaji merupakan salah satu unsur yang penting yang dapat mempengaruhi kinerja karyawan, sebab gaji adalah alat untuk memenuhi berbagai kebutuhan pegawai, sehingga dengan gaji yang diberikan pegawai akan termotivasi untuk bekerja lebih giat. ${ }^{6}$

\section{Upah}

Upah adalah hak pekerja yang diterima dan dinyatakan dalam bentuk uang sebagai imbalan dari pengusaha atau pemberi kerja kepada pekerja. Upah ditetapkan dan dibayarkan menurut suatu perjanjian kerja, kesepakatan, atau pertauran perundang-undangan termasuk tunjangan bagi para pekerja dan keluarganya atas

\footnotetext{
${ }^{5}$ Chatamarrasjid Ais. 2006, Badan Hukum Yayasan Cet.II, Bandung: PT Citra Aditya Bakti, hal.108.

${ }^{6} \mathrm{http}: / /$ jurnal-sdm.blogspot.com, gaji definisi peranan fungsi dan tujuan, di akses pada hari Sabtu, 24 April 2010, Pukul 10.08 WITA.
} 


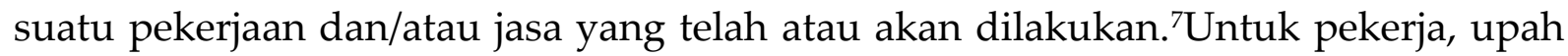
ditujukan untuk memenuhi kebutuhan hidup. Bagi pengusaha/pihak yang memberikan kerja, upah merupakan bagian dari biaya produksi (cost) yang akan berpengaruh pada harga jual barang-barang yang diproduksi. Sementara, bagi pemerintah yang mengeluarkan kebijakan, upah merupakan bagian dari pemerataan pembangunan.

\section{Honor}

Honor yakni berasal dari honour yang berarti penghormatan dalam dunia kerja bisa disebut pengorbanan atas jasa seseorang baik dalam bidang jasa maupun bidang lainnya atas jerih payah yang ia lakukan.

Honor adalah hak pekerja yang dibayarkan dan dinyatakan dalam bentuk uang sebagai imbalan dari pemberi kerja kepada pekerja yang ditetapkan dibayar merurut perjanjian suatu kerja ,kesepakatan dan peraturan yang ada, (Tanjung 2001). ${ }^{8}$

\section{Dasar Hukum Pemberian Gaji, Upah, dan/atau Honor}

Mengamati perkembangan yayasan baik pada waktu yang lalu maupun pada waktu yang sekarang ini, yayasan banyak digunakan untuk melakukan kegiatan usaha yang sulit dibedakan dengan lembaga/badan hukum yang bersifat komersil, sehingga dalam kenyataannya yayasan sering dijadikan sebagai cara untuk melakukan kegiatan usaha yang bersifat komersil. Undang-Undang Yayasan Nomor 16 Tahun 2001 memperbolehkan yayasan untuk melakukan kegiatan usaha yang bertujuan memperoleh laba dengan alasan agar yayasan tidak selamanya tergantung pada sumbangan dari masyarakat, negara ataupun bantuan dari negara lain. Hal ini tentunya menyimpang dari tujuan semula pendirian yayasan yang bertujuan sosial, keagamaan dan kemanusiaan. Kekayaan yayasan terpisah dari kekayaan pendiri. Selain itu, yayasan merupakan subjek hukum (entitas hukum) mandiri yang tidak bergantung dari keberadaan organ yayasan. Artinya, organ yayasan bukanlah pemilik yayasan melainkan sebagai pengelola kelangsungan hidup yayasan. Organ yayasan bertanggungjawab penuh terhadap pengelolaan kekayaan untuk mencapai maksud dan tujuan yayasan. Para pengurus yayasan termasuk pengawas, berkewajiban merencanakan, mengelola, dan mengendalikan kegiatan operasional yayasan serta menciptakan nilai tambah (value added) atau value for money, terhadap harta yayasan guna mencapai tujuan yang telah ditetapkan.

A. Brinz mengemukakan dalam teori kekayaan bertujuan bahwa hanya manusia yang dapat menjadi subjek hukum. ${ }^{9}$ Teori tersebut mendukung bahwa yayasan adalah milik masyarakat. Yayasan bukanlah miliknya pendiri atau pengurus melainkan adalah pihak yang dituju oleh pendirian/keberadaan yayasan tersebut. Dari pernyataan ini menunjukkan bahwa sebenarnya yayasan tidak hal. 126 .

${ }^{7}$ Rita, M. 2009. Risiko Hukum Bagi Pembina, Pengawas dan Pengurus Yayasan, Forum Sahabat, Jakarta,

8 , informasi pengolahan data, di akses pada hari Sabtu, Pukul 10.08 WITA.

${ }^{9}$ Chatamarrasjid Ais. 2006. Badan Hukum Yayasan Cet, II. PT Citra Aditya Bakti. Bandung, hal. 3. 
jelas siapa pemiliknya. Sebagai konsekwensi dari ketiadaan kepemilikan yayasan, maka muncul adanya larangan bagi organ yayasan untuk mendapatkan gaji, upah, atau honor. Selain itu, dalam Undang-undang yayasan dicantumkan larangan untuk memberikan kepada pihak ketiga, kecuali pemberian tunjangan sumbangan yang bersifat sosial dan kemanusiaan. Oleh karena itu kegiatan usaha yayasan bukan ditujukan untuk kepentingan pengurusnya, melainkan dipergunakan untuk kepentingan umum. Jadi penekanannya bukan pada keuntungan (profit) melainkan pada kemanfaatan (benefit).

Larangan pengalihan harta yayasan diatur dalam Pasal 5 ayat (1) Undangundang Nomor 28 Tahun 2004, bahwa kekayaan yayasan baik berupa uang, barang, maupun kekayaan lain yang diperoleh yayasan berdasarkan Undang-undang Yayasan, dilarang dialihkan atau dibagikan secara langsung, baik dalam bentuk gaji, upah, maupun honor, atau bentuk lain yang dapat dinilai dengan uang kepada pembina, pengurus, dan pengawas. Namun di dalam Undang-undang memberi pengecualiaan sebagaimana disebutkan Pasal 5 ayat (2) bahwa pengurus yayasan dapat menerima gaji, upah, atau honor apabila pengurus itu adalah :

a. Bukan pendiri yayasan dan tidak terafiliasi dengan pendiri, pembina dan pengawas. Terafiliasi adalah hubungan keluarga karena perkawinan atau keturunan sampai derajat ketiga, baik secara horizontal maupun vertikal.

b. Melaksanakan kepengurusan yayasan secara langsung dan penuh. Secara langsung dan penuh adalah melaksanakan tugas kepengurusan dengan ketentuan hari dan jam kerja yayasan bukan bekerja paruh waktu (part time)

Pemberian gaji, upah, atau honor sangat bergantung kepada situasi dan kondisi dari pengurus dan yayasan itu sendiri. Di bayar atau tidaknya serta jumlah yang dibayarkan kepada pengurus yayasan tergantung pada beberapa faktor antara lain; ${ }^{10}$ kedudukan, waktu dan cara kerja, serta berat ringannya pekerjaan yang harus dikerjakan. Kalau ia tidak dapat lagi mengerjakan pekerjaan lain, atau seluruh waktunya untuk yayasan, dan pekerjaan mereka dilakukan dengan profesional, kiranya layak bila memperoleh kompensasi, tetapi untuk penyantun seyogianya tidak dibayar.

Fakta yang terjadi di beberapa Yayasan berkaitan dengan pemberian gaji, upah atau honor, yaitu 4 yayasan yang diteliti tidak satupun di dalam anggaran dasar maupun anggaran rumah tangganya mengatur tentang larangan terhadap pengurus memperoleh gaji, upah atau honor. Wawancara dengan Ketua Umum Yayasan Peduli Pemulung (YAPEM), Abdul Rachman Nur mengatakan bahwa pemberian gaji di YAPEM wajib diberikan kepada Ketua Umum Yayasan, yang jumlahnya telah ditentukan oleh pendiri dan pengurus yayasan. Pemberian gaji kepada Ketua Umum

${ }^{10}$ Anwar Borahima. 2010. Kedudukan Yayasan di Indonesia Cet I. Kencana Prenada Media Group. Jakarta. Hal.160. 
yayasan diwajibkan dengan alasan bahwa hampir semua kerja/kegiatan yayasan ditangani langsung oleh Ketua Umum, dengan kata lain Ketua Umum yang memegang peranan penting dalam menjalankan yayasan. Alasan yang lain karena Ketua Umum tidak mempunyai pekerjaan lain, selain mengurus yayasan. Sedangkan organ (pengawas dan pengurus) yayasan tidak ada pemberian gaji melainkan pemberian honor, dengan syarat bahwa pendiri atau pengurus yayasan telah melakukan tugas yang sesuai dengan tujuan yayasan dan diseuaikan dengan jumlah kekayaan yayasan. Akan tetapi, ketentuan mengenai pemberian gaji dan honor tersebut tidak diatur di dalam Anggaran Dasar maupun Anggaran Rumah Tangga (AD/ART) YAPEM.

Begitupun di Yayasan Pendidikan ALIAH, Ketua Umum yayasan memperoleh hasil dari kegiatan yayasan yang dilakukan. Alasannya karena ketua adalah organ yang mengatur seluruh kegiatan yang dilaksanakan diruang lingkup yayasan. Kegiatan ini dilakukan oleh Badan Usaha yang didirikan dibawah Yayasan. Gaji diberikan kepada pegawai/pengurus harian yayasan yang bekerja di badan usaha yayasan. Pemberian gaji tersebut diatur oleh Ketua yang juga merangkap sebagai pendiri yayasan. Pegawai/pengurus harian yayasan tidak tercantum namanya di struktur kepengurusan yayasan. Sedangkan organ yayasan memperoleh gaji, upah, atau honor karena mereka tidak menjalankan kagiatan yayasan. Selain itu, pencantuman nama-nama di dalam struktur kepengurusan Yayasan Pendidikan ALIAH hanyalah sebuah simbol atau dengan kata lain organ tersebut ada yang tidak pernah bekerja sesuai tujuan yayasan. Hal tersebut tidak sesuai dengan jabatan yang diberikan kepada organ tersebut. Lain halnya dengan Yayasan Mutmainnatul Qulub yang tidak seorang pengurus pun memperoleh gaji, upah, atau honor. Gaji hanya diberikan kepada pegawai yang bertugas menjadi guru di sekolah yang didirikan oleh Yayasan tersebut. Akan tetapi, hal itu tidak diatur di dalam Anggaran Dasar Yayasan, hanya melaui kebijakan yang diputuskan oleh Organ Yayasan pada saat rapat tahunan.

Tidak diaturnya pemberian gaji kepada pegawai tersebut karena AD/ART yayasan berubah setiap pergantian pengurus yayasan. Di Yayasan Mutmainnatul Qulub, baik pengurus maupun pagawai atau pengurus harian tidak ada yang memperoleh gaji, upah, atau honor. Alasannya karena Yayasan ini sangat terbatas dalam hal keuangan. Kegiatan yayasan dapat dilaksanakan dengan memperoleh dana dari organ yayasan yang sifatnya tidak mengikat. Semua dana yang diperoleh, dipergunakan untuk melakukan kegiatan yang menjadi tujuan yayasan. Pengurus harian di yayasan ini bekerja tanpa mengharapkan imbalan. Akan tetapi, Ketua yayasan Nadrah El Hafidy mempunyai harapan dapat memberikan imbalan kepada pengurus harian jika kekayaan yayasan memungkinkan. Untuk sekarang ini, pemberian gaji belum dapat terlaksana karena jumlah keuangan Yayasan Mutmainnatul Qulub terbatas hanya untuk melakukan kegiatan yayasan. 


\section{Pemberian Sanksi Pidana Kepada Organ Yayasan yang Mendapatkan Gaji, Upah, atau Honor}

Sehubungan dengan pemberian gaji, upah, dan/atau honor tersebut, Undangundang Yayasan telah memberikan ketentuan berdasarkan Pasal 35 ayat (3) dan Pasal 6, yaitu dengan mengangkat pelaksana kegiatan yayasan. Pelaksana atau pengurus harian inilah yang melaksanakan kegiatan yayasan sehari-hari. Pasal 35 ayat (3) menjelaskan pengertian pengurus kegiatan yayasan adalah pengurus harian yayasan yang melaksanakan kegiatan yayasan sehari-hari. Pengurus harian ini tidak dilarang oleh Undang-undang Yayasan untuk menerima gaji, upah, atau honor dari kekayaan yayasan.

Pengurus yang mempunyai tugas dan tanggungjawab yang berat dan juga situasi perekonomian yang begitu buruk, tidak adil jika ketentuan yang melarang pengurus menerima upah atau honor tetap masih dipertahankan atau diperlakukan secara mutlak. Walaupun diketahui bahwa tujuan yayasan adalah bersifat sosial, keagamaan, dan kemanusiaan, sehingga seseorang yang melibatkan diri di dalam organ yayasan harus bekerja secara sukarela, tetapi jangan dilupakan bahwa mereka juga mempunyai tanggung jawab yang lain. ${ }^{11}$

Pemberian gaji, upah, dan/atau honor tersebut dapat dilakukan asal ketentuan itu diatur terlebih dahulu dalam anggaran dasar yayasan supaya mengikat semua personal yayasan. Ketentuan mengenai larangan itu wajib diperhatikan oleh organ yayasan, karena pelanggarannya merupakan sebuah kejahatan. Pasal 70 yang mengatur ketentuan pidana menyebutkan sebagai berikut :

1) Setiap anggota organ yayasan yang melanggar ketentuan sebagaimana dimaksud Pasal 5, dipidana dengan penjara paling lama 5 Tahun.

2) Selain pidana penjara, anggota oragan yayasan sebgaimana dimaksud dalam ayat (1) juga dikenakan pidana tambahan berupa kewajiban mengembalikan uang, barang, atau kekayaan yayasan yang dialihkan atau dibagikan.

Kejahatan yang diatur tersebut dapat disebut sebagai tindak pidana di bidang yayasan yang berupa mengalihkan atau membagikan harta kekayaan yayasan secara tidak sah, dan sebagai pelakunya adalah anggota pembina, pengurus, maupun pengawas yayasan. Maksud Undang-undang Yayasan sebenarnya bagus, karena hendak memberikan pidana tambahan berupa pengembalian uang atau kekayaan yayasan yang telah dialihkan oleh pelaku kejahatan, sehingga kekayaan itu dapat kembali kepada yayasan.

Organ yayasan yang melakukan kejahatan seperti mengambil kekayaan yayasan dalam bentuk apapun dianggap sebagai kejahatan, yaitu perbuatan melawan hukum yang bertentangan dengan anggaran dasar yayasan. Yayasan yang diduga melakukan kejahatan wajib diperiksa, berdasarkan Pasal 53 ayat (1).

${ }^{11}$ Anwar Borahima. 2010. Kedudukan Yayasan di Indonesia Cet I. Kencana Prenada Media Group. Jakarta. Hal.165. 
Selanjutnya dalam ayat (2) mengatur bahwa pemeriksaan sebagaimana dimaksud dalam ayat (1) hanya dapat dilakukan berdasarkan penetapan pengadilan atas permohonan tertulis pihak ketiga yang berkepentingan disertai alasan. Dari pasal tersebut, kejahatan seperti mengalihkan atau mengambil kekayaan yayasan dapat dikategorikan sebagai delik aduan. Alasannya karena pemeriksaan terhadap pengurus yayasan yang melakukan kejahatan tersebut dapat dieriksa jika ada pihak ketiga yang melakukan permohonan ke pengadilan. Terhadap permohonan itu, Pengadilan berhak menolak atau mengabulkan. Apabila pengadilan mengabulkan permohonan pihak ketiga, selanjutnya pengadilan mengeluarkan penetapan bagi pemeriksaan dan mengangkat paling banyak tiga orang ahli sebagai pemeriksa untuk melakukan pemeriksaan, Pasal 54 ayat (2) mengatur hal tersebut. Ahli adalah orang yang dianggap memiliki keahlian/kemampuan sesuai dengan masalah yang diperiksa. Pemeriksa ini mempunyai kewenangan untuk memeriksa semua dokumen dan kekayaan yayasan demi kepentingan pemeriksaan (Pasal 55 ayat 1). Organ (pembina, pengurus, pengawas), pelaksana kegiatan serta karyawan yayasan, wajib memberikan keterangan kepada pemeriksa (Pasal 55 ayat 2). Apabila pemeriksaan telah dilakukan, pemeriksa wajib menyampaikan laporan hasil pemeriksaan kepada Ketua Pengadilan di tempat kedudukan Yayasan paling lambat 30 hari terhitung sejak tanggal pemeriksaan selesai dilakukan (Pasal 56 ayat 1). Dari hasil pemeriksaan tersebut Pengadilan dapat memutuskan tentang pemberian sanksi kepada Pembina, pengurus, dan pengawas yayasan yang terbukti melakukan kejahatan.

Pemberian sanksi pidana kepada pengurus yang memperoleh gaji, upah, atau honor faktanya tidak diterapkan di empat yayasan yang diteliti oleh penulis. Yayasan Peduli Pemulung (YAPEM) yang melalui kebijakan organ yayasan, memberikan gaji yang besarnya sudah ditetapkan dan diberikan setiap bulan kepada Ketua Umum yayasan. Selain itu, honor juga diberikan kepada pengurus lain yang menjalankan pekerjaan yang sesuai dengan tujuan yayasan tersebut. Pemberian gaji dan honor tersebut sudah dilaksanakan sejak YAPEM memperoleh dana yang tetap dari pihak-pihak yang tidak mempunyai hubungan dengan yayasan. Akan tetapi, melalui wawancara antara penulis dengan Ketua Umum, diketahui bahwa danadana yang diperoleh yayasan, diperuntukkan untuk menjalankan kegiatan yayasan yang bergerak di bidang sosial kemasyarakatan. Yayasan Pendidikan ALIAH yang memberikan gaji kepada ketua dan pegawai/pengurus kegiatan yayasan juga tidak menerapkan sanksi pidana. Gaji diberikan kepada ketua karena yayasan tersebut adalah milik dari ketua yang juga merupakan pendiri yayasan. Menurut Alimuddin sebagai ketua Yayasan Pendidikan ALIAH, tidak diberikannya sanksi karena dianggap bahwa gaji diberikan sesuai dengan pekerjaan yang telah dilakukan oleh ketua dan pengurus kegiatan yayasan. Ketua dan pengurus ini telah memberikan tenaga dan pikirannya demi berjalannya kegiatan yayasan. Yayasan Nurul Islam Attaqwa tidak menerapkan sanksi pidana sesuai yang diatur Undang-undang yayasan 
karena tidak ada organ yang memperoleh gaji kecuali pegawai yang bekerja di sekolah yang didirikan oleh yayasan. Pegawai tersebut tidak menjabat sebagai pengurus di yayasan, murni sebagai pelaksana kegiatan yayasan.

Nampak dari hasil penelitian tersebut, tidak satupun yayasan yang menjadi objek peneliti yang menerapkan sanksi pidana kepada pembina, pengurus, dan pengawas yang memperoleh gaji, upah, atau honor dari kekayaan yayasan. Penulis mendapatkan beberapa faktor yang berkaitan dengan tidak diterapkannya pemberian sanksi pidana ini. Tidak diterapkannya sanksi pidana dikarenakan organ yayasan yang menganggap bahwa pemberian gaji sudah sesuai dengan kerja-kerja yang dilakukan oleh organ di masing-masing yayasan. Selain itu, tidak adanya instansi yang bertanggungjawab langsung terhadap pemberian sanksi kepada pengurus yang melakukan kejahatan. Faktor yang paling penting yaitu belum adanya kesadaran pengurus yayasan terhadap ketentuan pidana yang telah diatur di dalam Undang-undang Yayasan. Di dalam kenyataannya, ada pengurus yayasan yang sudah mengetahui jika melakukan kejahatan seperti mengambil kekayaan yayasan baik dalam bentuk uang atau barang mendapatkan sanksi pidana. Akan tetapi, karena kurangnya kesadaran dari pengurus peraturan yang telah ada tidak patuhi. Pengurus juga biasanya berlindung dibalik jabatannya sebagai pendiri yayasan yang mempunyai kekuasaan untuk menentukan benar atau salahnya tindakan yang dilakukan oleh para pengurusnya. Tidak diaturnya pemberian gaji, upah, atau honor kepada pengurus yayasan yang berhak yang tidak diatur di dalam anggaran dasar suatu yayasan juga menjadi salah satu faktor tidak adanya penerapan sanksi. Padahal Undang-undang Yayasan mengharuskan diaturnya pemberian gaji, upah atau honor di dalam anggaran dasar setiap yayasan.

\section{E. PENUTUP}

Undang-undang Yayasan Nomor 28 Tahun 2004 mengatur kekayaan yayasan dilarang untuk dialihkan atau dibagikan secara langsung maupun tidak langsung, baik dalam bentuk gaji, upah, ataupun honor, atau bentuk lain yang dapat dinilai dengan uang kepada pembina, pengurus, dan pengawas. Pengecualian diberikan kepada pelaksana kegiatan harian yang tidak terafiliasi dengan pendiri, pembina, dan pengawas serta melaksanakan kepengurusan yayasan secara langsung dan penuh, ditetapkan oleh pembina, berdasarkan kemampuan kekayaan yayasan. Akan tetapi, di dalam kenyataannya ada yayasan yang diteliti oleh penulis yang organnya (pembina/pendiri, pengurus, dan pengawas) mendapatkan gaji atau honor, seperti Yayasan Peduli Pemulung (YAPEM), Ketua Umum sekaligus pendiri yayasan mendapat gaji. Selain itu, Yayasan Pendidikan ALIAH yang ketua Umum yang merangkap sebagai pendiri yayasan memperoleh gaji dari kekayaan badan usaha yang didirikan oleh yayasan. Ada yang beralasan bahwa gaji diberikan karena pengurus yang telah bekerja sesuai dengan tujuan yayasan dan pengurus ini tidak 
mempunyai pekerjaan selain mengurus yayasan. Ini berarti dassein (hukum dalam kenyataannya) dan dassolen (hukum yang seharusnya) tidak dilaksanakan.

Kejahatan yang dilakukan oleh organ yayasan, seperti mengambil atau mengalihkan kekayaan yayasan dalam bentuk uang atau barang mendapatkan sanksi yang diatur di dalam Pasal 70 ayat (1) dan (2), yaitu sanksi penjara selama 5 tahun dan kekayaan yayasan yang sudah diambil harus dikembalikan. Pemberian gaji, upah, atau honor kepada pengurus yayasan yang tidak memenuhi syarat pada Pasal 5 Undang-undang Yayasan dianggap telah mengambil atau mengalihkan kekayaan yayasan dan itu termasuk sebagai tindak pidana. Dari hasil penelitian nampak bahwa ada pengurus yang melanggar ketentuan Pasal 70. Akan tetapi, tidak ada pemberian sanksi kepada pengurus tersebut.

\section{Daftar Pustaka}

Chatamarrasjid Ais. 2006, Badan Hukum Yayasan Cet.II, Bandung: PT Citra Aditya Bakti.

http://jurnal-sdm.blogspot.com, gaji definisi peranan fungsi dan tujuan, di akses pada hari Sabtu, 24 April 2010, Pukul 10.08 WITA.

Rita, M. 2009. Risiko Hukum Bagi Pembina, Pengawas dan Pengurus Yayasan, Forum Sahabat, Jakarta.

Chatamarrasjid Ais. 2006. Badan Hukum Yayasan Cet, II. PT Citra Aditya Bakti. Bandung.

Anwar Borahima. 2010. Kedudukan Yayasan di Indonesia Cet I. Kencana Prenada Media Group. Jakarta.

Anwar Borahima. 2010. Kedudukan Yayasan di Indonesia Cet I. Kencana Prenada Media Group. Jakarta. 